\title{
Human Rights and the International Criminal Court
}

Yvonne McDermott*

The International Criminal Court (ICC) was established in 1998, with the aim of ending impunity for the perpetrators of the most serious crimes of concern to the international community (ICC Statute, 1998, preamble). The ICC became operational in 2002 and by today, 122 states are parties to the ICC Statute. Final judgments have been issued in cases arising from situations in Mali, the Democratic Republic of the Congo, and the Central African Republic, and trials are ongoing for individuals alleged to have committed war crimes and/or crimes against humanity in Uganda, Côte d'Ivoire, and the Democratic Republic of the Congo. A number of suspects remain at large.

This chapter seeks to situate the ICC as an institution within the machinery of the international human rights legal framework. In so doing, it notes that the ICC is not itself a human rights court but that it nevertheless bears an important role in the protection, development, and interpretation of human rights. Part 1 examines the development of the ICC, and notes international criminal law's shared ancestry with international human rights law, insofar as both bodies of law were developed in the aftermath of World War II. Part 2 of this chapter discusses the interplay between human rights and the International Criminal Court, in particular examining the role of human rights organisations in providing evidence for ICC trials, and human rights law's status as a source of law before the ICC. Part 3 analyses the impact of the ICC in developing, protecting, and interpreting human rights. In setting out the four core

\begin{tabular}{llllll}
\hline *Associate Professor of $\quad$ Law, Swansea & University, & UK. & Email: \\
Yvonne.McDermottRees@swansea.ac.uk. & & &
\end{tabular}


crimes falling within the ICC's jurisdiction, it highlights that serious human rights violations can constitute international crimes. It also discusses the role of human rights in shaping the ICC's procedure and the right to a fair trial before the Court. In sum, this chapter demonstrates a symbiotic relationship between human rights and the ICC, in that human rights law bears an important influence over the law and practice of the ICC, while the ICC itself plays a role in the progressive development of human rights.

\section{The Development of the ICC and its Character as a Judicial Institution}

\section{The Parallel Development of Human Rights and International Criminal Law}

The founding international human rights legal instrument, the Universal Declaration on Human Rights (UDHR), was signed on 10 December 1948. The UDHR was clearly influenced by a recognition that the horrors suffered in the Second World War should never happen again; its preamble noted that 'disregard and contempt for human rights have resulted in barbarous acts which have outraged the conscience of mankind'. The UDHR, a non-binding instrument, led in turn to the twin binding international treaties of the International Covenant on Civil and Political Rights and the International Covenant on Economic, Social and Cultural Rights, both adopted in 1966. Since the adoption of these treaties, specialized UN treaties on human rights have been adopted; these include the Convention against Torture; the Convention on the Elimination of Discrimination against Women; the Convention on the Rights of the Child, and the Convention on the Rights of Persons with Disabilities, amongst others.

Most commentators trace the birth of international criminal law to the Treaty of 
Versailles in 1919, which publicly arraigned Kaiser Wilhelm II and stated that he would be tried by 'a special tribunal' comprised of five judges, one from each of the following: Great Britain, USA, France, Italy and Japan (Schabas, 2017, p.3; Cryer et al., p. 116; Treaty of Versailles, Article 227). This intention was ultimately unfulfilled after the Kaiser fled to Holland, which refused to extradite him (Schabas, 2017, p. 3; Bassiouni, 1997, p. 14). In August 1945, the Allied Powers created the International Military Tribunal (IMT) at Nuremberg, which was followed in 1946 by the International Military Tribunal for the Far East at Tokyo. The IMT issued its judgment on 1 October 1946, and in December of that year, the principles of law in the Nuremberg Tribunal's Charter and its judgment were affirmed by the UN General Assembly, which asked the International Law Commission (ILC) to commence work on 'a general codification of offences against the peace and security of mankind, or of an International Criminal Code’ (UNGA Resolution 95(I), 1946).

On 9 December 1948 (the day before the adoption of the UDHR), two significant developments in the creation of contemporary international criminal law emerged. First, the Genocide Convention was adopted, establishing an international crime of genocide that could be tried by domestic courts or 'such international penal tribunal as may have jurisdiction'. Relatedly, the General Assembly requested that the ILC begin work on the possibility of creating an international judicial body that could try international crimes (UNGA Resolution 280(III), 1948). Owing to Cold War politics, it would be 50 years before that permanent international criminal tribunal would be established. In the interim, two ad hoc international tribunals were created by the UN Security Council to prosecute those deemed most responsible for atrocities in the former Yugoslavia and Rwanda. Since 1998, international or 'internationalized' (i.e. hybrid creations of states' judicial systems with jurisdiction over international crimes 
and international judges) criminal tribunals have been established for Sierra Leone, Cambodia, East Timor, Lebanon, and Kosovo, amongst others (Romano et al., 2004).

Thus, the development of both international criminal law and international human rights law share a heritage that can be traced back to the end of the Second World War. That influence continues today - some 50 years after the adoption of the UDHR, the ICC noted, in a strikingly similar preambular paragraph to the UDHR's equivalent quoted above, that 'during this century millions of children, women and men have been victims of unimaginable atrocities that deeply shock the conscience of humanity.' The growth of both bodies of law reflects the individualization of international law, which had traditionally been the premise of states alone. As the International Criminal Tribunal for the former Yugoslavia (ICTY) noted, 'the impetuous development and propagation in the international community of human rights doctrines... has brought about significant changes in international law, notably in the approach to problems besetting the world community. A State-sovereigntyoriented approach has been gradually supplanted by a human-being-oriented approach.’ (Tadić, 1995, § 97)

\section{The ICC as a Human Rights Institution}

Unlike the ICTY and the International Criminal Tribunal for Rwanda (ICTR), the ICC does not have primacy over domestic courts. The ICTR and ICTY could demand that states defer to their jurisdiction and transfer defendants to stand trial before them, although they could choose to transfer cases of lower-level offenders to domestic jurisdictions if they were satisfied that the accused would receive a fair trial and would not be subject to the death penalty. Both the ICTY and ICTR could keep such 
transfers under review through trial monitoring, and demand that the domestic court transfer the accused back to the international tribunal if they were concerned that he or she was not receiving a fair trial or that there was a risk that the death penalty might be imposed (Gradoni, 2007). This monitoring role has now been passed to their successor institution, the Mechanism for the International Criminal Tribunals.

By contrast, under a principle known as complementarity, there is a preference that domestic trials be carried out for the crimes within the jurisdiction of the ICC. The ICC can only have jurisdiction over a case where a domestic state having jurisdiction over the same case is either unwilling or unable to put the accused on trial (El Zeidy, 2008; Kleffner, 2008).

In the Libya situation before the ICC, a debate arose as to whether the ICC could refuse to defer jurisdiction over two cases to Libya, where it seemed likely that the accused would be sentenced to the death penalty if convicted, and where there were doubts as to whether they could receive a fair trial. Libya argued that fair trial and death penalty considerations could not come into the Court's decision on jurisdiction, provided it was willing and able to put the accused on trial, because the ICC was not designed to act as a human rights court (Gaddafi, 2013, §§ 199-203). Ultimately, the ICC determined that the Libyan state was unable to try Saif Gaddafi because he was in the hands of rebels in Zintan, but that, notwithstanding concerns about his lack of access to counsel, Libya was both willing and able to try its former intelligence chief, Abdullah Al Senussi (Al Senussi, 2014, §§ 169-198). That being said, as I have argued elsewhere, the Al Senussi judgment did seemingly leave the possibility open to accepting fair trial concerns in future complementarity challenges (McDermott, 2016: p. 161). The Chamber noted that the failure to provide Al Senussi with a lawyer in advance of trial would not be such an egregious violation that would render the 
proceedings incapable of providing justice. This suggests that egregious violations of the right to a fair trial, such as, perhaps, the use of evidence obtained by torture, could reach that threshold and could be considered by the ICC in future complementarity cases.

Thus, unlike the ICTY and ICTR, the ICC does not have the capacity to consider such issues as the right to a fair trial and the death penalty when deferring jurisdiction to domestic courts. This weakens its position as a court committed to protecting human rights, compared to the ad hoc tribunals. Nevertheless, the ICC has the capacity to develop human rights law through its jurisprudence on the core international crimes and on the right to a fair trial of persons facing trial before it, as Parts 2 and 3 of this chapter demonstrate.

The Interplay between Human Rights and the ICC

\section{Human Rights as a Source of Law before the ICC}

Article 21(3) of the ICC Statute imposes an obligation on the Court to interpret its law

in a manner that is consistent with international human rights law. The Appeals Chamber in Lubanga determined that Article 21(3) means that the interpretation as well as the application of the law is subject to internationally recognised human rights. The Chamber held that, '[Article 21(3)] requires the exercise of the jurisdiction of the Court in accordance with internationally recognized human rights norms.' (Lubanga, 2006, § 36)

This obligation has been expounded upon in discussions on substantive aspects of the law. The Court has relied on human rights law in finding that the recruitment of child 
soldiers by non-state armed groups constitutes a war crime (Lubanga, 2012, Separate and Dissenting Opinion of Judge Odio Benito, § 13). Procedural human rights standards were instructive in interpreting the defendant's right to be informed of the charges against him (Lubanga, 2012, Dissenting Opinion of Judge Fulford, § 20). Where applying a provision of the ICC Statute would effectively breach human rights law, the ICC has held that the Court's human rights obligations must prevail (Katanga and Chui, 2011, § 73). As a result of this provision, the case law of human rights tribunals has been extensive before the ICC (Zeegers, 2016).

\section{The Interplay between Human Rights Organisations and the ICC}

Given its temporal and geographic distance from the crimes upon which it adjudges, and given the fallibilities of witness testimony, the ICC relies heavily on contemporaneous accounts of crimes. It is perhaps unsurprising that a large number of such accounts come from human rights organisations, working on the ground in the affected regions. Such evidence is not without its deficiencies - in Katanga, the Trial Chamber noted that 'the preparation of a report on an investigation of human rights violations is not subject to the same criteria as those for a criminal investigation', given that the sources of the information therein are often (anonymous) hearsay or oral testimony, and are not subjected to rigorous scrutiny by the author of the report in a manner akin to cross-examination (Katanga, 2014, § 326). Similarly, in Lubanga, the Chamber received evidence that 'human rights and humanitarian organizations are lousy criminal investigators. They are not producing forensic evidence that can be used by a Prosecutor’ (Lubanga, 2012, § 130).

On the other hand, the involvement of the Fédération Internationale des Ligues des Droits de l'Homme (FIDH) was crucial in the Bemba case. The FIDH had published a 
report in 2003 outlining crimes committed by Bemba's MLC troops in the Central African Republic. Bemba wrote to the FIDH's President, informing him that prosecutions would be undertaken for these crimes; the President, in turn, responded outlining some concerns on the sufficiency of those prosecutions, and encouraging Bemba to co-operate with the ICC (Bemba, 2016, §§ 607-611). This evidence was crucial in establishing the responsibility of Bemba as a commander over the MLC troops - having been made aware of the crimes, and having failed to adequately punish them, he bore responsibility under Article 28 of the ICC Statute. One would hope that over time, and with the advent of technologies that can record events and testimony and store it securely on remote servers, human rights organisations will become even more adept at gathering reliable evidence in a manner that is useful to the ICC and other courts.

\section{The Role of the ICC in Developing, Interpreting, and Protecting Human Rights}

\section{Core Crimes}

The ICC currently has jurisdiction over the crimes of genocide, crimes against humanity, and war crimes. It is likely that it will have jurisdiction over the crime of aggression at some time in the future, when two-thirds of states parties have ratified the amendments agreed upon at the ICC Review Conference at Kampala in 2010. Each of these crimes is closely related to human rights, and by adjudging upon them, the ICC, notwithstanding the fact that it is not formally part of the international human rights law framework, progressively develops human rights protection worldwide. It might be assumed that only breaches of civil and political rights (such as the right to life, right to be free from torture, right to a fair trial, and right to liberty) 
fall under the ambit of international criminal law. However, as Evelyne Schmid has convincingly argued, breaches of economic, social and cultural rights may also constitute international crimes, in certain circumstances (Schmid, 2015).

\section{Genocide}

Genocide, often dubbed 'the crime of crimes' is the commission of one of five prohibited acts (killing, causing serious bodily or mental harm, inflicting conditions of life calculated to bring about destruction; imposing measures to prevent births, and forcible transfer of children) against a national, ethnic, racial, or religious group with the intent to destroy that group (Schabas, 2009). Aside from a breach of the right to life implicit in the first of these acts, the other acts have clear human rights implications. In the situation relating to Darfur, Sudan, the Pre-Trial Chamber has issued a warrant of arrest against Sudanese President, Omar al-Bashir, for genocide under the form of serious bodily or mental harm, noting that acts of rape, torture, and forced displacement (all themselves human rights violations) had been committed (Bashir, 2010, § 30). Al-Bashir was also charged with imposing conditions of life calculated to bring about the destruction of the group, with the ICC noting that displacement, destroying a group's means of survival, usurpation of land, and denial of medical treatment could also be acts of genocide (Bashir, 2010, § 34).

\section{War Crimes}

War crimes are serious violations of the laws of armed conflict, and are criminalized under Article 8 of the ICC Statute for both international and non-international armed conflicts. The conduct that can constitute war crimes encompasses a broad range of human rights abuses, such as torture, murder, rape, pillage (thus denying victims' 
right to property) and the right to a fair trial. Article 8 also criminalizes certain conduct such as causing widespread, severe and long-lasting damage to the environment; using certain types of weapons and methods of warfare, and launching attacks against buildings dedicated to religion, education, art, science or charitable purposes, historic monuments, and hospitals. While these additional categories of war crimes do not explicitly link to a particular human right, their nexus to the human rights of those in affected territories is obvious. Environmental damage affects the right to health and the right to life; prohibited weapons can cause torture or inhumane treatment, and launching attacks against protected buildings and monuments impacts upon victims’ right to freedom of belief, education, culture, and health.

The ICC has not been afraid to extend the limits of the war crimes regime set down in the Statute to achieve greater protection for victims. Notably, a recent decision of the Appeals Chamber found that war crimes could be committed against fellow combatants from the same armed forces as the perpetrator. This runs contrary to conventional understandings and an ordinary reading of international humanitarian law, which seeks to protect certain categories of persons - civilians and those not directly taking part in hostilities, prisoners of war, and wounded, sick and shipwrecked combatants. The Appeals Chamber noted the 'seemingly unprecedented nature' of its findings, and the fact that it was unaware of any previous case where the international humanitarian law regime was applied to victims from the same armed forces as the perpetrator (Ntaganda, 2017, §§ 60, 67). Despite noting that Common Article 3 protects against inhumane treatment, 'requiring only that the persons were taking no active part in hostilities at the material time' (Ntaganda, 2017, § 60; emphasis added), the Appeals Chamber found that there was no reason to believe that international humanitarian law 'suggests any limits on who may be victims' of war 
crimes under the jurisdiction of the ICC (Ntaganda, 2017, § 64). As such, it declined to enter into any discussion as to whether the victims were actively participating in hostilities at the time, finding that the requirement that the persons were taking no active part in hostilities does not exist (Ntaganda, 2017, § 69). This is a remarkable volte-face in the space of fewer than ten paragraphs of a decision. Moreover, while this decision has been hailed as 'an enormously important contribution to international criminal law' (Grey, 2017), it does raise issues on the right to a fair trial and the principle of nullum crimen sine lege in practice (McDermott, 2017). Ironically, while attempting to broaden the scope of the ICC's jurisdiction to cover the heinous crimes suffered by the victims (which are undoubtedly crimes under national law, and might arguably be better suited to domestic prosecution), the ICC could be breaching another human right - the right to a fair trial - itself.

Another interesting issue on the interplay between international criminal law and international human rights law arises when both bodies of law prohibit the same conduct, but each bears different jurisdictional or definitional issues. This arose in the case of Kunarac before the ICTY, where torture was prosecuted as a war crime. Under the Convention against Torture, torture is defined as:

any act by which severe pain or suffering, whether physical or mental, is intentionally inflicted on a person for such purposes as obtaining from him or a third person information or a confession, punishing him for an act he or a third person has committed or is suspected of having committed, or intimidating or coercing him or a third person, or for any reason based on discrimination of any kind, when such pain or suffering is inflicted by or at the instigation of or with the consent or acquiescence of a public official or other person acting in an official capacity. It does not include pain or suffering arising only from, inherent in or incidental to lawful sanctions.

The problem for the prosecution in Kunarac was that the acts of torture committed were neither committed by or at the instigation of a public or state official, and nor 
were they for the purposes of obtaining information or a confession, or similar. To circumvent this issue, the ICTY noted that the Convention against Torture was addressed to states to prevent acts of torture being committed by states, and it was for that reason that the definition in the Convention focused on individuals acting on behalf of the state or its organs in an official capacity (Kunarac, 2002, § 146). Thus, while international human rights law does act as an interpretative guide for certain war crimes, the ICC and other international criminal tribunals may see fit to derogate from the definitional limits set down in human rights, by examining the object and purpose of human rights statutes vis-à-vis international criminal law statutes.

\section{Crimes against Humanity}

Crimes against humanity occur when certain acts are committed as part of a widespread or systematic attack against a civilian population. Article 7 of the ICC Statute enumerates 11 acts that constitute crimes against humanity when committed as part of such an attack. They are: murder, torture, rape and other forms of sexual violence, enslavement, deportation, extermination, deprivation of liberty, enforced disappearances, apartheid, persecution, and other inhumane acts of similar gravity. As with war crimes, the parallels between the underlying acts and human rights violations are clear. Some crimes against humanity, such as enforced disappearance and apartheid, are themselves subject to international treaties, but Article 7 represents the first time that such violations have been defined as international crimes falling within the jurisdiction of an international criminal court (Schabas, 2016: pp. 202206). Two specific crimes against humanity - persecution and other inhumane acts are very closely linked to international human rights law and, as such, warrant further elucidation. 
Persecution is defined as the intentional and severe denial, contrary to international law, of a fundamental right on the basis of political, racial, national, ethnic, cultural, religious, gender, or other grounds that are recognised as impermissible under international law. In Blé Goudé, the Pre-Trial Chamber considered that rapes, murders and injuries committed by forces loyal to former Côte d'Ivoire President, Laurent Gbagbo, against perceived supporters of Alassane Ouattara in the wake of an election lost by Gbagbo could constitute acts of persecution. Interestingly, the Chamber found that the acts were committed not just on political grounds, but also on ethnic, national and religious grounds, as members of certain ethnic, national and religious groups were presumed to be Ouattara supporters and targeted on that basis (Blé Goudé, 2014, $\S \S 123-124)$. Persecution might also cover situations where the victims were denied the right to employment, to liberty, to a proper judicial process, or other fundamental rights as part of a discriminatory pattern of behaviour (Nilsson, 2011, p. 233).

The crime of 'other inhumane acts' constitutes conduct of a similar character to the enumerated acts constituting crimes against humanity, which intentionally cause great suffering or serious bodily injury or physical or mental health. One recent debate that has arisen in the jurisprudence of the ICC is whether the practice of forced marriage constitutes a separate crime against humanity, falling under other inhumane acts. Article 7 already includes slavery as a crime against humanity, and sexual slavery as a separate crime against humanity. Thus, the question arises as to whether a third form of criminalization for the same conduct is necessary, or whether it would be preferable to prosecute forced marriage as either slavery or sexual slavery. In Katanga, the ICC preferred the latter approach, finding that the crime of sexual slavery adequately encompassed acts of forced marriage (Katanga, 2008, §§ 428433). By contrast, the Chamber in Ongwen found that forced marriage may qualify as 
a separate crime against humanity under 'other inhumane acts', and that the practice differed from sexual slavery 'in terms of conduct, ensuing harm, and protected interests.' (Ongwen, 2016, §§ 87-95) This example shows that the ICC's jurisprudence continues to evolve and develop to incorporate new interpretations of the law, in order to punish offenders for serious human rights violations. The creativity of international judges in interpreting the law has been widely discussed in the literature (Darcy and Powderly, 2010; Shahabuddeen, 2014).

\section{Aggression}

The Nuremberg and Tokyo Tribunals tried individuals for the crime of planning, preparing, initiating, or waging a war of aggression, or a war in violation of international legal instruments. Since then, no international criminal tribunal has prosecuted a defendant for this crime. It was agreed at the drafting of the ICC Statute that the Court should exercise jurisdiction over the crime of aggression. However, the state parties negotiating the ICC Statute could not agree upon a definition of this crime. In particular, there was debate over the jurisdictional issues surrounding the crime, such as whether the Prosecutor could launch an investigation acting proprio motu (on her own initiative) or on the basis of a referral by a state party. Because of these difficulties, no definition of aggression was included in the Statute upon its adoption in 1998. Instead, Article 5(2) noted that the Court would exercise jurisdiction over the crime once a definition and provisions on the exercise of jurisdiction had been agreed in accordance with the review and amendment process set out in Articles 121 and 123 of the Statute.

That agreement was ultimately reached at the ICC Review Conference in Kampala in 2010. There are two jurisdictional pre-conditions for the ICC's jurisdiction over this 
crime; first, 30 states must ratify the amendments (Palestine became the $30^{\text {th }}$ state to ratify the amendments in June 2016), and second, some time after 1 January 2017, a two-thirds majority of states parties must take a decision permitting the Court to exercise jurisdiction over the crime in the future.

What does the crime of aggression mean for the ICC's role in protecting human rights? Aggression has traditionally been seen as a state crime, with the victims being not individuals, but the state whose sovereignty, territorial integrity, or political independence has been interfered with by the aggressor state. It is perhaps owing to this perception that high-profile human rights groups like Amnesty International and Human Rights Watch took a rather indifferent approach to the aggression amendments at the Kampala Review Conference (Schabas, 2012: p. 207). However, there is no question that acts of aggression between states can have a devastating impact on the human rights of citizens in affected territories, not least the right to life. A stand-alone right to peace was recognised by the UN General Assembly in 1984, noting that 'life without war serves as the primary international prerequisite for the material well-being, development and progress of countries, and for the full implementation of the rights and fundamental human freedoms proclaimed by the United Nations' (UNGA Resolution 39/11, 1984). If and when the ICC gains jurisdiction over this crime, it will bear a key role in developing the right to peace.

\section{Procedure and the Right to a Fair Trial}

The most notable influence of human rights law over the ICC has been in the realm of international criminal procedure, and as regards the right to a fair trial in particular. The ICC borrows extensively from international human rights courts and instruments in determining the rights of the accused. For example, in Ruto and Sang, the 
Prosecutor had challenged the Trial Chamber's decision permitting Kenya’s Deputy President Ruto to be voluntarily absent from trial. The Appeals Chamber, in upholding the decision, held that the right of the accused to be present at trial could be voluntarily waived. It found support for this position in the case law of the European Court of Human Rights, ICTR case law, and the African Commission on Human and Peoples’ Rights' Principles and Guidelines on the Right to a Fair Trial and Legal Assistance in Africa (Ruto, 2013, § 51). Human rights have also been relied upon extensively in decisions on equality of arms (Lubanga, 2008, Partly dissenting opinion of Judge Pikis, § 14); witness protection measures (Katanga, 2009, §§ 32-33), the right to be informed of the charges, and ensuring that trials are both expeditious and fair (Katanga, 2013, Dissenting Opinion of Judge Cuno Tarfusser, § 8; Katanga, 2010, Dissenting Opinion of Judge Erkki Kourula and Judge Ekaterina Trendafilova, $\S 42)$.

Not only does the ICC borrow extensively from human rights law, it also bears an illustrative function in demonstrating best practices to states, and providing an example of an international criminal procedure based on a mixed procedural model that is both closely modelled on, and bound to respect, international human rights standards. Amnesty International, in its most recent version of its Fair Trial Manual, relies on the standards of international criminal procedure in illustrating fair procedural standards. Thus, even though the Court refused to assume the role of a human rights court in examining the admissibility of the Al-Senussi case discussed in Part 2 above, this does not mean that it seeks to derogate from human rights standards in developing its own procedural practice. Indeed, the Court declares in its public literature that '[i]n all of its activities, the ICC observes the highest standards of fairness and due process.' (ICC, 2015) 


\section{Conclusion}

The ICC, as the world's first permanent international criminal institution, plays an important role in the global legal framework for the promotion, protection and fulfillment of human rights, despite the fact that it is not, itself, a human rights court. Unlike the ad hoc tribunals that preceded it, the ICC does not have primacy of jurisdiction, and this means that it cannot deem a case admissible before it purely on the basis that the accused would not receive a fair trial in a domestic court. This, from the outside, appears to weaken the ICC's position as a cog in the machine of human rights protection.

However, the ICC is bound to interpret its law in a manner that is consistent with international human rights law, and human rights standards have had a significant bearing on the development of international criminal law before the ICC. Conversely, the ICC has been able to bring about progressive developments in the interpretation of its core crimes, all of which are closely linked to human rights. In this manner, international criminal tribunals have influenced the development of human rights and international law more broadly. The synergies between human rights and the ICC's legal framework are not limited to substantive legal issues. There is also evidence of an interplay between human rights and the ICC in procedural matters, especially in issues surrounding the accused's right to a fair trial, and in investigations, where human rights organisations play a not insignificant role in the collection and preservation of evidence. Thus, the relationship is mutually beneficial in that human rights law informs and shapes ICC law and procedure, and ICC practice in turn feeds into the development of human rights law.

It is apposite to end this chapter with a note of caution on expectations. As has been 
seen in this chapter, the ICC is but one Court, with jurisdiction over tightly defined crimes and an obligation to respect the presumption of innocence and try cases in accordance with the criminal standard of proof beyond reasonable doubt. It is sometimes expected to play a greater role in international politics, by ending conflicts, deterring future atrocities, or forcing states to respect their human rights obligations, and is then found wanting against those unrealistic expectations. Despite the notable developments set out in this chapter, it is important to remember that the ICC is but one small part of a vast and often unwieldy machine of international justice, which comprises a range of bodies with different mandates, operational structures and powers. To quote the ICC Prosecutor, in her recent statement on the situation in Libya:

To those of you who express to my Office your fears and disappointments, as well as your hopes and aspirations for the future of a Libya grounded on the pillars of justice where gross human rights violations are distant memories of the past, your calls for action do not fall on deaf ears... And while I am under no illusions that the International Criminal Court is a panacea - it surely is not - I, along with my team, are committed to playing our part. (ICC Prosecutor, 2017)

Ultimately, that is the best we can hope for with the ICC - that it will play its small part in the global march towards universal human rights, justice, and the rule of law. 


\section{Further Reading}

Jones, Annika (2016) 'Insights Into an Emerging Relationship: Use of Human Rights Jurisprudence at the International Criminal Court' Human Rights Law Review 16 (No. 4), pp. 701-729.

Margueritte, Thomas (2010) 'International Criminal Law and Human Rights' in William A. Schabas and Nadia Bernaz (eds) Routledge Handbook of International Criminal Law (Abingdon, UK: Routledge) 435-452.

Mariniello, Triestino, and Lobba, Paolo (eds) (2017) Judicial Dialogue on Human Rights: The Practice of International Criminal Tribunals (Leiden: Brill/Nijhoff).

McDermott, Yvonne (2016) Fairness in International Criminal Trials (Oxford: Oxford University Press).

Shelton, Dinah (ed.) (2000) International Crimes, Peace, and Human Rights: The Role of the International Criminal Court (New York: Transnational Publishers).

Schabas, William A. (2016) The International Criminal Court: A Commentary on the Rome Statute ( $2^{\text {nd }}$ edn., Oxford: Oxford University Press).

Schabas, William A. (2017) An Introduction to the International Criminal Court (5 ${ }^{\text {th }}$ edn., Cambridge: Cambridge University Press).

Schmid, Evelyne (2015) Taking Economic, Social, and Cultural Rights Seriously in International Criminal Law (Cambridge: Cambridge University Press).

Zeegers, Krit (2016) International Criminal Tribunals and Human Rights Law (The Hague: Springer). 


\section{Bibliography}

\section{$\underline{\text { A. Primary Sources }}$}

i. International Legal Instruments

Treaty of Peace between the Allied and Associated Powers and Germany ('Treaty of Versailles') (1919) TS 4.

Agreement for the Prosecution and Punishment of the Major War Criminals of the European Axis, and Charter of the International Military Tribunal. London, 8 August 1945.

United Nations General Assembly Resolution 95(I), 11 December 1946.

United Nations General Assembly Resolution 280(III), 9 December 1948.

Convention on the Prevention and Punishment of the Crime of Genocide, 78 UNTS 227, 9 December 1948.

Universal Declaration on Human Rights, General Assembly Resolution 217A (III), 10 December 1948.

United Nations General Assembly Resolution 39/11, 12 November 1984.

Convention Against Torture and Other Cruel, Inhuman or Degrading Treatment or Punishment, 1465 UNTS 85, 10 December 1984.

Rome Statute of the International Criminal Court ('ICC Statute'), UN Doc. A/CONF.183/9, 17 July 1998.

\section{ii. $\quad$ Case Law}

\section{International Criminal Court}

Situation in the Democratic Republic of the Congo: Prosecutor v. Lubanga, Judgment on the Appeal of Mr. Thomas Lubanga Dyilo against the Decision on the Defence Challenge to the Jurisdiction of the Court pursuant to article 19 (2) (a) of the Statute of 3 October 2006, Case No. ICC-01/04-01/06, ICC, Appeals Chamber, 14 December 2006.

Situation in the Democratic Republic of the Congo: Prosecutor v. Lubanga, Judgment on the appeals of The Prosecutor and The Defence against Trial Chamber I's Decision on Victims' Participation of 18 January 2008, Case No. ICC-01/04-01/06, ICC, Appeals Chamber, 11 July 2008.

Situation in the Democratic Republic of the Congo: Prosecutor v Katanga and Chui, Decision on the Confirmation of Charges, Case No. ICC-01/04-01/07, ICC, Pre-Trial 
Chamber I, 30 September 2008.

Situation in the Democratic Republic of the Congo: Prosecutor v Katanga and Chui, Decision on the Protection of Prosecution Witnesses 267 and 353 of 20 May 2009, Case No. ICC-01/04-01/07, ICC, Trial Chamber II, 28 May 2009.

Situation in Darfur, Sudan: Prosecutor v. Al Bashir, Second Decision on the Prosecution's Application for a Warrant of Arrest, Case No. ICC-02/05-01/09, ICC, Pre-Trial Chamber I, 12 July 2010.

Situation in the Democratic Republic of the Congo: Prosecutor v Katanga and Chui, Judgment on the Appeal of Mr Katanga Against the Decision of Trial Chamber II of 20 November 2009 Entitled "Decision on the Motion of the Defence for Germain Katanga for a Declaration on Unlawful Detention and Stay of Proceedings, Case No. ICC-01/04-01/07, ICC, Appeals Chamber, 28 July 2010.

Situation in the Democratic Republic of the Congo: Prosecutor v Katanga and Chui, Decision on an Amicus Curiae application and on the "Requête tendant à obtenir présentations des témoins DRC- D02- P- 0350, DRC- D02- P- 0236, DRC- D02P- 0228 aux autorités néerlandaises aux fins d'asile" (articles 68 and 93(7) of the Statute), Case No. ICC-01/04-01/07, ICC, Trial Chamber II, 9 June 2011.

Situation in the Democratic Republic of the Congo: Prosecutor v. Lubanga, Judgment pursuant to article 74 of the Statute, Case No. ICC-01/04-01/06, ICC, Trial Chamber I, 4 April 2012.

Situation in the Democratic Republic of the Congo: Prosecutor v Katanga and Chui, Judgment on the appeal of Mr Germain Katanga against the decision of Trial Chamber II of 21 November 2012 entitled 'Decision on the implementation of regulation 55 of the Regulations of the Court and severing the charges against the accused persons', Case No. ICC-01/04-01/07, ICC, Appeals Chamber, 27 March 2013.

Situation in Libya: Prosecutor v. Gaddafi and Al-Senussi, Decision on the admissibility of the case against Saif Al-Islam Gaddafi, Case No. ICC-01/11-01/11, ICC, Pre-Trial Chamber I, 31 May 2013.

Situation in Kenya: Prosecutor v. Ruto and Sang, Judgment on the appeal of the Prosecutor against the decision of Trial Chamber V(a) of 18 June 2013 entitled 'Decision on Mr Ruto's Request for Excusai from Continuous Presence at Trial', Case No. ICC-01/09-01/11, ICC, Appeals Chamber, 25 October 2013.

Situation in the Democratic Republic of the Congo: Prosecutor v. Katanga, Judgment pursuant to article 74 of the Statute, Case No. ICC-01/04-01/07, ICC, Trial Chamber II, 7 March 2014.

Situation in Libya: Prosecutor v. Gaddafi and Al-Senussi, Judgment on the appeal of Mr Abdullah Al-Senussi against the decision of Pre-Trial Chamber I of 11 October 2013 entitled "Decision on the admissibility of the case against Abdullah AlSenussi””, Case No. ICC-01/11-01/11, ICC, Appeals Chamber, 24 July 2014. 
Situation in Côte d'Ivoire: Prosecutor v. Blé Goudé, Decision on the confirmation of charges against Charles Blé Goudé, Case No. ICC-02/11-02/11, ICC, Pre-Trial Chamber I, 11 December 2014.

Situation in the Central African Republic: Prosecutor v. Bemba, Judgment pursuant to article 74 of the Statute, Case No. ICC-01/05-01/08, ICC, Trial Chamber III, 21 March 2016.

Situation in Uganda: Prosecutor v. Ongwen, Decision on the confirmation of charges against Dominic Ongwen, Case No. ICC-02/04-01/15, ICC, Pre-Trial Chamber II, 23 March 2016.

Situation in the Democratic Republic of the Congo: Prosecutor v. Nataganda, Judgment on the appeal of $\mathrm{Mr}$ Ntaganda against the "Second decision on the Defence's challenge to the jurisdiction of the Court in respect of Counts 6 and 9", Case No. ICC-01/04-02/06, ICC, Appeals Chamber, 15 June 2017.

\section{International Criminal Tribunal for the former Yugoslavia}

Prosecutor v. Tadić, Decision on the Defence Motion for Interlocutory Appeal on Jurisdiction, Case No. IT-94-1-AR72, ICTY, Appeals Chamber, 2 October 1995.

Prosecutor v. Kunarac, Kovac and Vukovic, Judgment, Case Nos. IT-96-23 \& IT-9623/1-A, ICTY, Appeals Chamber, 12 June 2002.

\section{iii. $\quad$ Official Statements}

ICC Prosecutor (2017), Statement of ICC Prosecutor to the United Nations Security Council on the Situation in Libya, 8 May 2017, online at https://www.icccpi.int/legalAidConsultations?name=170509-otp-stat-lib.

\section{B. Secondary Sources}

Bassiouni, M. Cherif (1997), 'From Versailles to Rwanda in Seventy-Five Years: The Need to Establish a Permanent International Criminal Court' Harvard Human Rights Journal 10, pp. 11-62.

Cryer, Robert; Friman, Robert; Robinson, Darryl, and Wilmshurst, Elizabeth (2014) An Introduction to International Criminal Law and Procedure ( $3^{\text {rd }}$ edn., Cambridge: Cambridge University Press).

Darcy, Shane and Powderly, Joseph (eds.) (2010) Judicial Creativity at the International Criminal Tribunals (Oxford: Oxford University Press).

El Zeidy, Mohamed (2008) The Principle of Complementarity in International Criminal Law (Leiden/Boston: Martinus Nijhoff). 
Gradoni, Lorenzo (2007) “"You will Receive a Fair Trial Elsewhere”: The Ad Hoc International Criminal Tribunals Acting as Human Rights Jurisdictions' Netherlands International Law Review 54 (No. 1), pp. 1-49.

Grey, Rosemary (2017) 'ICC Appeals Chamber Issues “Unprecedented” Decision on War Crimes of Rape and Sexual Slavery', IntLawGrrls, 14 June 2017, online at https://ilg2.org/2017/06/14/icc-appeals-chamber-issues-unprecedented-decision-onwar-crimes-of-rape-and-sexual-slavery.

International Criminal Court (2015) Reporting on the International Criminal Court: A Practical Guide for the Media, online at https://www.icccpi.int/iccdocs/PIDS/publications/ICC_Guide_for\%20Journalists_EN.pdf.

Kleffner, Jann K. (2008) Complementarity in the Rome Statute and National Criminal Jurisdictions (Oxford: Oxford University Press).

McDermott, Yvonne (2016) Fairness in International Criminal Trials (Oxford: Oxford University Press).

McDermott, Yvonne (2017) 'ICC extends War Crimes of Rape and Sexual Slavery to Victims from Same Armed Forces as Perpetrator', IntLawGrrls, 5 January 2017, online at https://ilg2.org/2017/01/05/icc-extends-war-crimes-of-rape-and-sexualslavery-to-victims-from-same-armed-forces-as-perpetrator/.

Nilsson, Jonas (2011) 'The Crime of Persecution in the ICTY Case Law' in Bert Swart, Alexander Zahar and Göran Sluiter (eds) The Legacy of the International Criminal Tribunal for the Former Yugoslavia (Oxford: Oxford University Press) pp. 219-246.

Romano, Cesare P.R.; Nollkaemper, André and Kleffner, Jann K. (2004) Internationalized criminal courts and tribunals: Sierra Leone, East Timor, Kosovo, and Cambodia (Oxford: Oxford University Press)

Schabas, William A. (2009) Genocide in International Law: The Crime of Crimes $\left(2^{\text {nd }}\right.$ edn., Cambridge: Cambridge University Press).

Schabas, William A. (2012) Unimaginable Atrocities (Oxford: Oxford University Press).

Schabas, William A. (2016) The International Criminal Court: A Commentary on the Rome Statute ( $2^{\text {nd }}$ edn., Oxford: Oxford University Press).

Schabas, William A. (2017) An Introduction to the International Criminal Court (5 ${ }^{\text {th }}$ edn., Cambridge: Cambridge University Press).

Schmid, Evelyne (2015) Taking Economic, Social, and Cultural Rights Seriously in International Criminal Law (Cambridge: Cambridge University Press).

Shahabuddeen, Mohamed (2004) 'Does the Principle of Legality Stand in the Way of 
the Progressive Development of the Law?' Journal of International Criminal Justice 2, pp. 1007-1017. 